\title{
Assessment of Hydrocarbon Oil Spill Pollutants in Agricultural Land
}

\author{
R. Arivarasan ${ }^{1}$, D. Sathishkumar ${ }^{2}$ and M. Rengasamy ${ }^{3}$ \\ ${ }^{1}$ PG Scholar, ${ }^{2}$ Teaching Fellow, ${ }^{3}$ Assistant Professor, \\ Department of Petrochemical Engineering, University College of Engineering, \\ BIT Campus, Trichirapalli, Tamil Nadu, India \\ E-Mail: arivarasan1994@gmail.com
}

\begin{abstract}
Hydrocarbon contamination is a very serious problem whether it comes from petroleum, pesticides or other toxic organic matters. Oil spill have number of effects on the environment when petroleum products are released into the environment, they interact with the soil, groundwater, and microorganisms. Studies have mainly focused on identifying and characterizing these hydrocarbon degrading microbes, as well as how they scope with the soil/water/hydrocarbon interface, and how to improve this capacity. The main aim of the present study was to evaluate the biodegradation potential of microbes which was isolated from the hydrocarbon contaminated soil such as bacillus species and pseudomonas species. Those isolated microbes were inoculated into the contaminated soil, after 20 days of degradation process the physicochemical properties such as $\mathbf{p H}$, temperature, color, GC-MS were analyzed and also prominent microbe was identified from the isolated microbes. Comparative study also done between aerated and non-aerated condition from that, aeration process enhanced the degradation rate.

Keywords-Biodegradation, Contaminated soil, Environment, Hydrocarbon
\end{abstract}

\section{INTRODUCTION}

The biodegradation of petroleum and other hydrocarbons in the environment is a complex process, who's quantitative and qualitative aspects depend on the nature and amount of the oil or hydrocarbons present, the ambient and seasonal environmental conditions, and the composition of the autochthonous microbial community. Microbial degradation of oil has been shown to occur by attack on aliphatic or light aromatic fractions of the oil, with high molecular weight aromatics, resins, and asphaltenes considered to be recalcitrant or exhibiting only very low rates of biodegradation although some studies have reported their removal at high rates under optimal conditions. In aquatic ecosystems, dispersion and emulsification of oil in oil slicks appear to be prerequisites for rapid biodegradation; large masses of mousse, tar balls, or high concentrations of oil in quiescent environments tend to persist because of low surface areas available for microbial activity. Petroleum spilled on or applied to soil is largely adsorbed to particulate matter, decreasing its toxicity but possibly also contributing to its persistence.

Biodegradation rates generally increase with increasing temperature; ecosystems exposed to extremely low temperatures degrade hydrocarbons very slowly. The microbial degradation of petroleum in aquatic environments is limited primarily by nutrients such as nitrogen and phosphorus; salinity and pressure may be important in estuarine and deep-sea regions, respectively. Oxygen, nutrient concentrations, moisture, and $\mathrm{pH}$ are predominant factors in determining biodegradation rates in soil. Since oil items incorporate a ton of regular fuel, clearly oil spills may occur at high rates and in numerous areas, including local locations. Surface oil spills are anything but difficult to distinguish, and will leave obvious traces, for example, oil stains, and moreover other trademark signs, for example, smells because of the vapours emitted from the spilled oil. The underground oil spills are harder to get but then might be trickier (oil may reach groundwater more effectively and go with it). Both surface and underground oil spills can possibly defile soils, silt, water (groundwater and surface water bodies), and air (because of numerous volatile compounds produced by the spilled oil into the air).

\section{EFFECTS ON THE GENERAL POPULATION}

The effects of oil spills on humans may be direct and indirect, depending on the type of contact with the oil spill.

\section{A. Direct Exposure to Oil Spills}

It occurs close to where people live or work and where they may come in contact with oil spill components by breathing contaminated air - since oil and products (petroleum products) have many volatile compounds which are emitted as gases from spilled oil, the air becomes contaminated with those volatile oil products or vapours producing specific odours. Even when odours are not felt, a health risk may exist for some individual compounds if residents are exposed (breathe the air) for a long time. Of course, when the smell is obvious the health risk increases. Once in the air, contamination may travel over long distances. Of course, that vapours will also become more diluted with the distance travelled. So, the original contamination levels at the source along with specific weather conditions may dictate the final spreading of oil contaminated air vapours. By direct contact with the skin - people may come in direct contact with oil and/or oil products while walking in a contaminated area (e.g., beach). An initial irritation will be obvious. Additionally, contaminants may be absorbed through the skin and enter the body. 


\section{B. Indirect Exposure to Oil Spills}

It affects even when people live in places far from where the actual oil spill took place by bathing in contaminated water for example swimming in a contaminated water stream even when oil sheen may not be visible, dissolved oil contaminants may exist in the water if it was impacted by an oil spill.

By eating contaminated food some oil compounds bioaccumulate in living organisms and may become more concentrated along the food chain. Humans may become food that could be orders of magnitude higher than in the contaminated environment. This is especially problematic since residents could be exposed even if they live far away from an oil spill if they consume food coming from a spill affected area.

The main oil spill effects include a variety of diseases, negative economic impact, pollution with crude oil or petroleum products (distillates such as: gasoline, diesel products, jet fuels, kerosene, fuel oil, as well as heavy distillates like hydraulic and lubricating oils) and the aesthetic issues that affect the residents of the affected areas in multiple ways.

The negative economic impact is a major effect of oil spill pollution. It can affect the community where the oil spill occurred in a number of ways, among which the following are the most important issues,

Long-term ceasing of activities such as fishing in the polluted waters that affects fishermen and fisheries if a very large amount of oil is spilled; for example, the BP oil spill in the Gulf of Mexico had already impacted many local fishermen's and fisheries' normal activity, and this looks like a long-term effect due to the very large amount of spilled oil. Effects on local fishermen are detailed below.

Property value reduction depends on the magnitude of the oil spill and affects all the properties in a certain area exposed to oil spill pollution; this negative effect on property value applies not only to those properties directly affected by the oil spill, but to all the properties in a certain area exposed to oil spill pollution or at risk of becoming polluted at some point in time.

\section{MATERIALS AND METHOD}

\section{A. Sample Area and Collection}

The soil sample is fertile clay alluvial soil collected from the oil contaminated agricultural land. Soil samples were collected from the contaminated area at two different depths $15 \mathrm{~cm}$ and $30 \mathrm{~cm}$ respectively and the collected sample transferred immediately to the laboratory where the hydrocarbon degrading bacteria were isolated from them.

\section{B. Sample Preservation}

Samples were collected into zip type plastic bags and placed in $1 \mathrm{~L}$ wide mouth glass jars with Teflon lined cap and sealed. Each individual sample was prepared and separately stored in sealed bags. These were put into appropriate containers and stored in the laboratory fridge at $4^{\circ} \mathrm{C}$.

\section{Culture Media}

The principal method for the detection of bacteria from clinical specimens is by culture on solid culture media. Bacteria grow on the surface of culture media to produce distinct colonies. Different bacteria produce different but characteristic colonies, allowing for early presumptive identification and easy identification of mixed cultures. There are many different types of culture media. Agar is used as the gelling agent to which is added a variety of nutrients (e.g. blood, peptone and sugars) and other factors (e.g. buffers, salts and indicators). Culture media are nonselective (e.g. blood agar, nutrient agar) and these will grow a wide variety of bacteria. While some e.g. MacConkey agar are more selective (in this case through the addition of bile salts selecting for the 'biletolerant' bacteria found in the large intestine such as Escherichia coli and Enterococcus faecalis). MacConkey agar also contains lactose and an indicator system that identifies lactose-fermenting coliforms (e.g. Escherichia coli, Bacillus sps.) from lactose-non fermenting coliforms (e.g. Morganella Salmonella).

Media can be made even more selective by the addition of antibiotics or other inhibitory substances, and sophisticated indicator systems can allow for the easy detection $n$ of defined bacteria from mixed populations.

\section{Isolation and Identification of Hydrocarbon Degrading Bacteria}

Hydrocarbon degrading bacteria were isolated by an enrichment culture technique in $10-\mathrm{ml}$ broth medium and 10 g of contaminated soil incubated at $37^{\circ} \mathrm{C}$ for 24 hours. Preliminary identification of individual bacterial isolates was obtained by classical tests. Such identification included the shape of cells, gram staining and colony morphology on solid nutrient media. In this case two microbes were isolated from the contaminated soil named as Klebsiella pneumoniae and Bacillus sps, they were adopted for degradation process. The isolated bacteria were identified according to the biochemical characteristics.

\section{E. Experimental Procedure for Physiochemical Analysis}

Physicochemical parameters were also determined in order to characterize contaminated. These parameters included $\mathrm{pH}$, Color. Characterization of the soil sample was carried out before and after the treatment to determine the efficiency of the treatment. $\mathrm{pH}$ was measured using $\mathrm{pH}$ meter. 
TABLE I CHARACTERISTICS OF RAW SOIL SAMPLE

\begin{tabular}{|c|c|}
\hline Parameter & Value \\
\hline $\mathrm{pH}$ & 7.82 \\
\hline Color & Brown \\
\hline
\end{tabular}

\section{F. Petroleum Hydrocarbon Biodegradation by Isolated Bacteria}

Gas chromatography method.- Isolated bacteria were inoculated into 40-ml test tubes, each containing $20 \mathrm{ml}$ basic mineral medium plus $2 \mathrm{ml}$ light oil as source of carbon and were agitated at $180 \mathrm{rpm}$ at $30^{\circ} \mathrm{C}$ for 3 days on a rotary shaker before being subjected to analysis by gas chromatography (GC). Total petroleum biodegradation was determined by comparison of the total areas of the chromatograms containing isolated bacteria with those of the controls.

\section{RESULT AND DISCUSSION}

The collected soil sample had a loamy texture and the organic matter content in the soil was about 30\%. Gas chromatographic analysis is done before biodegradation of the sample, it reveals that the soil sample contained compounds of benzene 1,3,5 trimethyl, mesitylene, benzene 1-ethyl, 3-methyl, decane, undecane, dodecane, naphthalene, decahydro, spiro [3,5] nona-5,7-dien-1one, 5,9,9-trimethyl in higher concentrations as shown in Fig 1.

\section{TABLE II AFTER TREATMENT OF 3 DAYS}

\begin{tabular}{|c|c|}
\hline Isolated Bacteria & Degradation Rate (\%) \\
\hline Bacillus sp. & 15 \\
\hline Klebsiella pneumoniae & 9 \\
\hline
\end{tabular}

Survival of microorganisms in petroleum hydrocarbons medium after their inoculation is a key deciding factor in the rate of biodegradation of hydrocarbons either in soil or in liquid phase (Ramos et al., 1991). Since all the bacteria in the present study were isolated from a petroleum contaminated soil sample, they survived and adopted the oil contaminated soil/liquid environment very easily as also reported by other authors (Rahman et al., 2003; Sugiura et al., 1997). The bacterial species isolated from the collected soil sample are Klebsiella pnemoniae and Bacillus sps. Comparatively Bacillus sps shows higher degradation efficiency than Klebsiella pnemoniae.

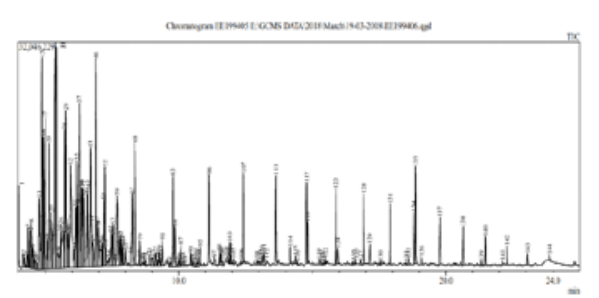

Fig 1 GC MC Analysis of Soil Sample Before Degradation

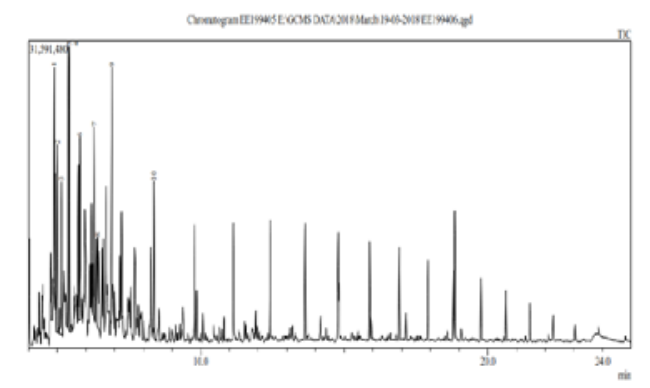

Fig. 2 GC MC Analysis of Soil Sample After Degradation

\section{CONCLUSION}

In conclusion, the findings in this study showed that Klebsiella pneumoniae and Bacillus sps could be useful in bioremediation of sites highly contaminated with crude petroleum-oil hydrocarbons. The thermophilic nature of these bacteria could add further advantage for their use in bioremediation of petroleum contaminated soils in tropical countries.

\section{REFERENCES}

[1] A. Kapley, H. J. Purohit, S. Chhatre, R. Shanker and T. Chakrabarti, "Osmotolerance and hydrocarbon degradation by a genetically engineered microbial consortium”, Bioresour Technol, Vol. 61, pp. 241-245, 1999.

[2] M. P. Díaz, J. W. Steve, S. J. W. Grigson, C. J. Peppiatt and G. J. Burgess, "Isolation and characterization of novel hydrocarbondegrading euryhaline consortia from crude oil and mangrove sediments”, Mar Biotechnol, Vol. 2, pp. 522-532, 2000.

[3] D. Freitag, L. Ballhorn, H. Geyer and F. Korte, "Environmental Hazard profile of Organic Chemicals. Chemosphere”, Vol. 14, pp. 1589-1616, 1985.

[4] Department of Environmental Conservation - DEC, Petroleum contaminated soil guidance policy. Spills technology and related series (STARS). Revised. New York State; 1992.

[5] C. M. A. Iwegbue, G. E. Nwajei and F. O. Arimoro, "Characteristic level of total petroleum hydrocarbon in soil, sediment and surface water of an oil impacted area in the Niger Delta”, Pakistan Journal of Scientific and Industrial Research, Vol. 50, No. 4, pp. 247-250, 2007.

[6] M. A. Chukwujindu, E. S. Iwegbue, and G. E. Nwaje, "Characteristic levels of total petroleum hydrocarbon in soil Profile of automobile mechanic waste dumps", International Journal of Soil Science, Vol. 3, No. 1, pp. 48-51, 2008.

[7] E. O. Ekudanyo and O. O. Obuekwe, "Effect of Oil spill on soil physicochemical properties of a spill site in a Typical Udipsamment of Niger Delta basin of Nigeria”, Environmental Monitoring and Assessment. Springer Netherlands, Vol. 60, No. 2, pp. 235-249, 2004.

[8] P. C. Onianwa, Essien, "Petroleum hydrocarbon levels in sediments of stream and river within Ibadan city, Nigeria”, Bull. Chem. Soc. Ethiopia, Vol. 13, pp. 83-85, 1999.

[9] F. J. Santos and M. T. Galceran, "The Application of gas chromatography to Environmental analysis," Trends in Analytical Chemistry, Vol. 21, No. 9-10, pp. 672-685, 2002.

[10] M. Marvin and M. Christopher, GC/MS. A practical user's guide. WileyVCH. New York. 1998.

[11] D. A. Skoog, D. M. West, F. J. Holler and S. R. Crouch, "Fundamentals of analytical chemistry", 8th Edition. Brooks/Cole. Thomson Learning, USA. 2004.

[12] G. Miguel and G. Salvador, "Strategies for the rapid characterization of metals and organic pollutants in solid wastes and contaminated soils by using mass spectrometry", Trends in Analytical Chemistry, Vol. 17, pp. 263-272, 1998. 
[13] A. T. N. Akinlua and T. R. Ajayi, "Determination of rare earth elements in Niger Delta crude oils by inductively coupled plasmamass spectrometry”, Fuel, Vol. 87, pp. 1469-1477, 2008.

[14] A. A. Algadi and H. M. Al Swaidan, "Determination of vanadium in Saudi Arabian crude oil by inductively coupled plasmamass spectrometry”, Anal Lett. Vol. 23, No. 9, pp. 1757-1764, 1990.

[15] V. W. Hendrik, V. J. G. Guido, L. Richard, and B. Dianne, "Application of comprehensive two-dimensional gas chromatography for the assessment of oil contaminated Soils," Journal of Chromatography A. Vol. 1, No. 137, pp. 91-100, 2006.

[16] T. Barkay, S. Navon-Venezia, E. Z. Ron and E. Rosenberg, "Enhancement of solubilization and biodegradation of polyaromatic hydrocarbons by the bioemulsiWer Alasan”, Appl. Environ. Microbiol. Vol. 65, pp. 2697-2702, 1999.

[17] A. E. Burger, "Estimating the mortality of seabirds following oilspills - eVects of spill volume”, Mar. Pollut. Bull. Vol. 26, pp. 239-248, 1993.

[18] K. A. Burns, S. D. Garrity and S. C. Levings, "How many years until mangrove ecosystems recover from catastrophic oil-spills", Mar. Pollut. Bull., Vol. 26, pp. 239-248, 1993.

[19] S. Chhatre, H. Purohit, R. Shanker and P. Khanna, "Bacterial consortia for crude oil spill remediation”, Water Sci. Technol. Vol. 34, pp. 187-193. 1996.

[20] M. A. Cubitto, A. C. Moran, M. Commendatore, M.N. Chiarello, M.D. Baldini and F. Sineriz, "EVects of Bacillus subtilis O9 biosurfactant on the bioremediation of crude oil-polluted soil", Biodegradation, Vol. 15, pp. 281- 287, 2004.

[21] Z. Cybulski, E. Dziurla, E. Kaczorek and A. Olszanowski, “The inXuence of emulsiWers on hydrocarbon biodegradation by Pseudomondacea and Bacillacea strains. Spill Sci”, Technol. Bull. Vol. 8, pp. 503-507, 2003.

[22] K. Das and A. K. Mukherjee, "Characterization of biochemical properties and biological activities of biosurfactants produced by
Pseudomonas aeruginosa mucoid and non-mucoid strains isolated from hydrocarbon-contaminated soil samples", Appl. Microbiol. Biotechnol, Vol. 69, pp. 192-199, 2005.

[23] K. Das and A. K. Mukherjee, "DiVerential utilization of pyrene as sole source of carbon by Bacillus subtilis and Pseudomonas aeruginosa strains: Role of biosurfactants in enhancing the bioavailability”. J. Appl. Microbiol.

[24] J. P. Del'Arco and F.P. de Franca "InXuence of oil contamination levels on hydrocarbon biodegradation in sandy sediment. Environ”, Pollut. Vol. 112, pp. 515-519, 2001..

[25] M. D. Ferrari, E.Neirotti, C. Albornoz, M.R. Mostazo, M. Cozzo, "Biotreatment of hydrocarbons from petroleum ta nk bottom sludge in soil slurries”, Biotechnol. Lett., Vol. 18, pp.1241-1246, 1996.

[26] D. T. Gibson and V. Subramanian, "Microbial degradation of aromatic hydrocarbon. In: Gibson, D.T. (Ed.), Microbial Degradation of Organic Compounds”, Vol. 13. Marcel Dekker, Inc, New York, NY, pp. 181-242, 1984.

[27] M. O. Ilori and D. I. Amund, "Degradation of anthracene by bacteria isolated from oil polluted tropical soils”, Z. Naturforsch, Vol. 55, pp. 890-897, 2000.

[28] R. A. Kanaly and S. Harayama, "Biodegradation of high-molecular weight polycyclic aromatic hydrocarbons by bacteria", $J$. Bacteriol., Vol. 182, pp. 2059-2067, 2000.

[29] M. D. Lee and C. H. Ward, "Environmental and biological methods for the restoration of contaminated aquifers", Environ. Toxicol. Chem. 4, 743-750, 1985. .

[30] O.H. Lowry, N.J. Rosebrough, A.L. Farr and R.J. Randall, "Protein measurement with the folin phenol reagent", J. Biol. Chem. Vol. 193, pp. 265-275, 1951.

[31] C. G. MacElwee, H. Lee and J. T. Trevors, "Production of extracellular emulsifying agent by Pseudomonas aeruginosa UG1”, J. Ind. Microbiol, Vol. 5, pp. 25-32, 1990. 